\title{
Hubungan Mean Arterial Pressure (MAP) Dengan Preeklamsia Pada Ibu Hamil Di Puskesmas Bontobangun Kabupaten Bulukumba
}

\author{
${ }^{1}$ Ely Kurniati \\ ${ }^{2}$ Rusnawati
}

${ }^{1}$ DIII Kebidanan Stikes Panrita Husada Bulukumba, Indonesia
${ }^{2}$ DIII Kebidanan Stikes Panrita Husada Bulukumba, Indonesia

Alamat Korespondensi:

Nama Koresponden : Ely Kurniati

Bagian/area kepakaran penulis : Kebidanan

Institusi penulis : Stikes Panrita Husada Bulukumba

No.Hp / telfn : 085242438980

Email penulis : elyarie368@gmail.com 


\begin{abstract}
ABSTRAK
Preeklamsia mempersulit 4-7\% dari kehamilan dan tetap menjadi penyebab utama morbiditas dan mortalitas ibu dan janin di seluruh dunia. Meskipun perbaikan dalam perawatan kesehatan selama dekade terakhir, preeklampsia tetap penyebab paling umum kedua kematian ibu di Indonesia. Penelitian ini bertujuan Untuk mengetahui apakah mean arterial pressure (MAP) berhubungan dengan kejadian preeklamsia pada ibu hamil di Puskesmas Bontobangun kabupaten bulukumba periode tahun 2018 s.d 2019Penelitian ini menggunakan deskriptif analitik dengan pendekatan Historical Cohort Studies, yaitu dengan melihat pada buku kohor ibu riwayat hasil pengukuran tekanan darah pada Ibu Hamil di Puskesmas Bontobangun Kabupaten Bulukumba periode tahun 2018 s.d 2019. Menentukan sampel dengan metode pengambilan sampel yang diambil secara purposive sampling. 31 julmah sampel ibu hamil yang mengalami preeklamsia dan 31 kontrol yaitu ibu hamil dengan kondisi normal yang memiliki kriteria tertentu (matching) dengan sampel. Hasil penelitian menjelaskan bahwa dari hasil uji $\mathrm{T}$ berpasangan, nilai $\alpha>0.037$ sehingga dikatakan ada hubungan antara mean artery pressure (MAP) dengan kejadian preeklamsia pada ibu hamil di puskesmas Bontobangun periode tahun 2018 s.d2019.
\end{abstract}

Kata Kunci : Preeklamsia, Kehamilan, Mean Arterial Pressure

\begin{abstract}
ABSTRAK
Preeclampsia complicates 4-7\% of pregnancies and remains the leading cause of maternal and fetal morbidity and mortality worldwide. Despite improvements in health care over the last decade, preeclampsia remains the second most common cause of maternal mortality in Indonesia. This study aims to determine whether the mean arterial pressure (MAP) is related to the incidence of preeclampsia in pregnant women at the Bontobangun Puskesmas, Bulukumba district for the period 2018 to 2019. This research uses a descriptive-analytic approach with Historical Cohort Studies, namely by looking at the cohort book of the history of blood pressure measurement results for pregnant women at the Bontobangun Public Health Center, Bulukumba Regency for the period 2018 to 2019. Determining the sample using the sampling method taken by purposive sampling. 31 samples of pregnant women who experienced preeclampsia and 31 controls were pregnant women with normal conditions who had certain criteria (matching) with the sample. The results explained that from the paired T-test results, the value of $\alpha>0.037$ so that it is said that there is a relationship between mean artery pressure (MAP) and the incidence of preeclampsia in pregnant women at Bontobangun puskesmas for the period 2018-2019.
\end{abstract}

Keywords: Preeclampsia, Pregnancy, Mean Arterial Pressure 


\section{PENDAHULUAN}

Preeklamsia mempersulit $4-7 \%$ dari kehamilan dan tetap menjadi penyebab utama morbiditas dan mortalitas ibu dan janin di seluruh dunia. Meskipun perbaikan dalam perawatan kesehatan selama dekade terakhir, preeklampsia tetap penyebab paling umum kedua kematian ibu di Indonesia.(Griffin \& Shennan, 2014).

Kematian ibu adalah kematian perempuan saat hamil atau kematian dalam kurun waktu 42 hari sejak terminasi kehamilan tanpa memandang lamanya kehamilan atau tempat persalinan, yakni kematian yang disebabkan karena kehamilannya atau pengelolaannya, tetapi bukan karena sebab-sebab lain seperti kecelakaan, terjatuh, dan lain-lain, atau banyaknya wanita yang meninggal dari suatu penyebab kematian tekait dengan gangguan kehamilan (Nurjasmi, Emi, 2016).

Berdasarkan data dari kementerian kesehatan republik indonesia tahun 2017 angka kematian ibu per $100.000 \mathrm{KH}$ masih jauh dari target SDGs yaitu, pada tahun 2007 AKI sebanyak 228, pada tahun 2012 meningkat tajam 359 dan pada tahun 2015 mengalami penurunan 305 (Darmawan, 2019).

Dari data yang diperoleh dari dinas kesehatan Kabupaten Bulukumba, pada tahun 2014 terdapat kematian ibu sebanyak 11 orang, 7 orang yang diakibatkan oleh preeklamsia $(63,63 \%)$, tahun 2015 terdapat kematian sebanyak 7 orang, dengan kematian yang diakibatkan oleh eklamsia sebanyak 3 orang atau (42,85\%). Tahun 2016 terdapat kematian sebanyak 4 orang, dan tahun 2017 terdapat kematian sebanyak 7 orang dengan kematian yang diakibatkan oleh hipertensi dalam kehamilan sebanyak 3 orang (42,85\%).(Ely Kurniati, n.d.).

Preeklamsia (PE) prevalensi sekitar 24\% dari semua nancies (Duley, 2009). Di negara maju PE adalah salah satu penyebab utama morbiditas ibu (Mayrink et al., 2018) dan bertanggung jawab atas sekitar 14\% dari semua kematian terkait kehamilan (Chaiworapongsa et al., 2014a). Dari sudut pandang janin, PE dikaitkan dengan peningkatan risiko morbiditas dan mortalitas perinatal, yang bertanggung jawab atas sekitar 10\% kelahiran mati (Gardosi et al., 2005) dan 12-16\% kelahiran prematur (Dhariwal dan Lynde, 2017).(Orosz et al., 2019).

Bukti yang signifikan sekarang menunjukkan bahwa tes skrining gabungan untuk PE mengungguli skrining berdasarkan riwayat dan sekarang direkomendasikan oleh Society of Ultrasound in Obstetrics and Gynecology (ISUOG) dan International Federation of Gynecology and Obstetrics (FIGO) [9-11] . Algoritme yang disediakan oleh Fetal Medicine Foundation (FMF) menggabungkan karakteristik dan riwayat ibu dengan hasil biofisik (tekanan arteri rata-rata (MAP), indeks pulsasi arteri uterine rata-rata 
(UtA-PI)) dan pengukuran biokimia (faktor pertumbuhan plasenta serum).(Wertaschnigg et al., 2019).

Berbagai upaya pemerintah telah dilakukan dalam menangani preeklamsi, salah satunya dengan deteksi dini preeklamsi dengan cara screening ibu hamil yang berisiko, namum belum ada kebijakan program khususnya di kabupaten Bulukumba untuk melakukan screening faktor resiko preeklamsia dengan melihat Mean Arerial Pressure (MAP) pada ibu hamil. Berdasaran latar belakang di atas maka penulis tertarik mengangkat penelitian yang berjudul "Hubungan Mean Arterial Pressure Dengan Preeklamsia Pada Ibu Hamil Di Puskesmas Bontobangun Kabupaten Bulukumba Periode Tahun 2018 - 2019”.

\section{METODE}

Ditinjau dari tujuan penelitian yang akan dicapai, maka penelitian ini menggunakan studi analitik dengan pendekatan Historical Cohort Studies, yakni melihat pada buku kohor ibu mengenai riwayat tekanan darah pada ibu hamil usia kehamilan kurang dari 20 minggu yang diambil secara purposive sampling. Dengan jumlah sampel 31 per kelompok, (sugiono, 2012). Penelitian dilakukan pada Maret s.d Agustus 2020 di Puskesmas Bontobangun, Kecamatan Rilau Ale Kabupaten Bulukumba.

\section{HASIL}

Tabel 1 menunjukkan bahwa data ibu hamil yang mengalami preeklamsial di puskesmas bonto bangun periode tahun 20182020 sebanyak 31 responden. dilihat dari segi umur di dominasi oleh kelompok yang tidak berisiko (umur 20-35 tahun) yaitu sebanyak $24(77.4 \%)$ dan selebihnya $7 \quad(22.6 \%)$ responden yang kategori berisiko yaitu umur >35 Tahun. Dari aspek paritas terlihat bahwa responden multipara lebiih banyak dari primi, dimana jumlah multi sebanyak 17 (54.8\%) sedangkan multipara sebanyak 14 (45.2\%). Adapun nilai mean artery pressure (MAP) pada tabel di atas menunjukkan kelompok tidak berisiko yaitu nilai MAP $\leq 90$ mendominasi pada responden sebanyak (77.4\%), sedangkan yang berisiko sebanyak 7 (22.6\%) responden.

Tabel 2 menunjukkan bahwa data ibu hamil yang normal sebagai kontrol di puskesmas bonto bangun periode tahun 20182020 sebanyak 31 responden. dilihat dari segi umur di dominasi oleh kelompok yang tidak berisiko (umur 20-35 tahun) yaitu sebanyak $24(77.4 \%)$ dan selebihnya $7 \quad(22.6 \%)$ responden yang kategori berisiko yaitu umur >35 Tahun. Dari aspek paritas terlihat bahwa responden multipara lebiih banyak dari primi, dimana jumlah multi sebanyak 17 (54.8\%) sedangkan multipara sebanyak 14 (45.2\%).

Adapun nilai mean artery pressure (MAP) pada tabel di atas menunjukkan kelompok tidak berisiko yaitu nilai MAP $\leq 90$ mendominasi pada responden sebanyak 29 (93.5\%), sedangkan yang berisiko sebanyak 2 (6.5\%) responden.

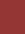


Dari tabel di atas terlihat bahwa dari hasil uji $\mathrm{T}$ berpasangan, nilai $\alpha>0.037$ sehingga dikatakan ada hubungan antara mean artery pressure (MAP) dengan kejadian preeklamsia pada ibu hamil di puskesmas Bontobangun periode tahun 2018 s.d 2019.

\section{PEMBAHASAN}

Dari data hasil penelitian menujukkan bahwa data ibu hamil yang megalami preeklamsia dan ibu hamil yang normal sebagai kontrol sama-sama berjumlah 31 orang. Dilihat dari segi umur dan paritas kedua kelompok responden memiliki karakteristik yang sama yaitu di dominasi oleh kelompok yang tidak berisiko (umur 2035 tahun) yaitu sebanyak $24(77.4 \%)$ dan selebihnya 7 (22.6\%) responden yang kategori berisiko yaitu umur $>35$ Tahun dan dari aspek paritas terlihat bahwa responden multipara lebiih banyak dari primi, dimana jumlah multi sebanyak 17 (54.8\%) sedangkan multipara sebanyak 14 (45.2\%).

Terdapat beberapa pernyataan tentang preeklampsia yang terjadi umumnya pada wanita primigravida, Kintiraki et al (2015) dalam penelitiannya menyimpulkan bahwa wanita nulipara tiga kali lipat berpotensi mmengalami preeklampsia. Penelitian yang dilakukan Agustin (2014) bahwa ibu hamil nullipara mengalami preeclampsia terbanyak yaitu $59 \%$ dari total sampel dan sejalan dengan data dari POGI (2016) bahwa nullipara memiliki risiko preeklampsia hampir 3 kali lipat (RR 2,91 95\% CI 1,28 $6,61)$.

Adapun perbedaan dari kedua kelompok terlihat dari nilai mean artery pressure (MAP), pada kelompok ibu hamil yang mengalami preeklamsia ditemukan kategori tidak berisiko (nilai MAP $\leq 90$ ) mendominasi pada responden sebanyak (77.4\%), sedangkan yang berisiko sebanyak 7 (22.6\%) responden. sedangkan pada kelompok kontrol kategori tidak berisiko sebanyak 29 (93.5\%), dan yang berisiko hanya $2(6.5 \%)$ responden. dengan demikian terlihat perbedaan nilai MAP pada kedua kelompok tersebut, yaitu responden yang preeklamsia cenderung memiliki nilai MAP yang berisiko atau bernilai di atas 90 .

Adapun hasil hasil uji $\mathrm{T}$ berpasangan secara numerik ditemukan nilai $\alpha>0.037$ sehingga dikatakan ada hubungan antara mean artery pressure (MAP) dengan kejadian preeklamsia pada ibu hamil di puskesmas Bontobangun periode tahun 2018-2019. Hasil penelitian ini sejalan dengan penelitian yang telah dilakukan oleh Marco dkk yang meneliti tentang Signifikansi klinis dari peningkatan tekanan darah arteri rerata pada trimester kedua dan peningkatan ambang batas dalam tekanan darah sistolik atau diastolik selama trimester ketiga. hasil penelitiannya menujukkan bahwa Populasi penelitian terdiri dari 700 wanita primigravida normotensif muda yang dievaluasi secara prospektif selama kehamilan. Tekanan darah sistolik dan 
diastolik diukur dengan hati-hati pada setiap kunjungan prenatal, dan tekanan darah arteri rata-rata pada trimester kedua dihitung untuk setiap pengukuran. Rata-rata $>90 \mathrm{mmHg}$ dianggap abnormal.

Seratus tiga puluh tujuh pasien memiliki preeklamsia, dengan insidensi keseluruhan 19,6\%. Rata-rata > $90 \mathrm{mmHg}$ memiliki sensitivitas $8 \%$ dan nilai prediksi positif $23 \%$. Nilai masing-masing untuk peningkatan ambang > $15 \mathrm{mmHg}$ dalam tekanan diastolik adalah $39 \%$ dan $32 \%$. Untuk peningkatan ambang batas $>30$ $\mathrm{mmHg}$ dalam tekanan sistolik, nilainya $22 \%$ dan $33 \%$. Nilai prediktif negatif untuk semua tes yang dipelajari berkisar antara $81 \%$ dan $85 \%$. Baik tekanan darah arteri rata-rata pada trimester kedua > $90 \mathrm{~mm} \mathrm{Hg}$ maupun peningkatan tekanan darah sistolik atau diastolik selama trimester ketiga secara signifikan memprediksi perkembangan preeklampsia (Villar L. \& Sibai, 1989). Demikian pula American Collage of Obstetricians and Gyhaecologists (ACOG) menyatakan bahwa faktor risiko untuk kajian klinis risiko preeklamsia yaitu Primipara, Riwayat preeklamsia, Hipertensi kronik, Penyakit ginjal kronik, Riwayat thrombophilia, Kehamilan multipel, IVF ( invitro fertilization), Riwayat preeklamsia dalam keluarga, Diabetes melitus typer 1 dan 2, Obesitas, SLE (systemic lupus erythematosus), Usia ibu > 40 th (EFENDI LUKAS, 2018).
Faktor risiko untuk kajian klinis risiko preeklamsia menurut National Institute of Health and Care Excellence (NICE) yaitu Risiko Tinggi jika ada Riwayat hipertensi pada kehamilan sebelumnya, Hipertensi kronik, Diabetes Melitus type 1 dan 2, Penyakit ginjal kronik, Penyakit autoimun (SLE dan APS) dan Risiko sedang jika Primipara, Obesitas (IMT > $35 \mathrm{~kg} / \mathrm{m} 2$ ), Riwayat preeklamsia dalam keluarga, Usia ibu > 40 tahun, Jarak kehamilan sebelumnya $>10$ thn, Kehamilan multiple (EFENDI LUKAS, 2018),

Dari kedua organisasi di atas dapat disimpulkan bahwa untuk mendeteksi kejadian preeklamsia penting untuk dilakukan pendeteksian tekanan darah lebih dini, agar dapat diambil langkah antisipasi sedini mungkin. Menentukan mean artery pressure (MAP) pada usia kehamilan kurang dari 20 minggu ini merupakan salah satu langkah awal yang dapat dilakukan dalam mendeteksi dini kejadian preeklamsia. Pernyataan ini diperkuat oleh Prawirohardjo (2009) bahwa terjadinya preeklampsia dapat dideteksi secara dini dengan memakai Mean Arterial Pressure Test (MAP) dengan Sensitifitas 93\% dan Spesifisitas 62\%, dan dilakukan pada kehamilan 18-26 minggu. Mean Arterial Pressure (MAP) mampu menjadi prediktor hipertensi dalam kehamilan, dimana Kuc, et al. (2013) mengatakan MAP adalah alat yang ampuh untuk memprediksi preeklampsia pada 
trimester awal kehamilan dan menghasilkan tingkat detekesi yang tinggi (72\%).

\section{KESIMPULAN DAN SARAN}

Nilai mean artery pressure (MAP) ibu hamil dengan preeklamsia menunjukkan kelompok tidak berisiko sebanyak (77.4\%), sedangkan yang berisiko sebanyak 7 (22.6\%) responden. Nilai mean artery pressure (MAP) ibu hamil normal menunjukkan kelompok tidak berisiko sebanyak 29 (93.5\%), sedangkan yang berisiko sebanyak 2 (6.5\%) responden. Ada hubungan antara mean artery pressure (MAP) dengan kejadian preeklamsia pada ibu hamil di puskesmas Bontobangun periode tahun 2018-2019.

Hasil penelitian ini dapat menjadi bahan referensi untuk peneliti selanjutnya, selain itu juga dapat menjadi bahan masukan dan rekomendasi bagi Pemerintah Kabupaten Bulukumba khususnya di puskesmas bontobangun dalam membuat kebijakan yang lebih terarah dan berfokus pada deteksi dini preeklamsia pada ibu hamil.

\section{DAFTAR PUSTAKA}

Darmawan, D. (2019). Profil Kesehatan Indonesia. In Journal of Chemical Information and Modeling (Vol. 53, Issue 9). https://doi.org/10.1017/CBO978110741 5324.004

EFENDI LUKAS. (2018). DETEKSI DINI PREEKLAMSIA.

Ely Kurniati. (n.d.). The Relationship Between Preeclampsia And Low Birth Weight Infants In H.Andi Sulthan Daeng Radja Bulukumba. https://doi.org/https://doi.org/10.37362/j lb.v2i3.288
Griffin, M., \& Shennan, A. H. (2014). aplikasi klinis biomarker pada preeklampsia (Vol. 8, Issue 4).

Nurjasmi, Emi, et al. (2016). No Buku Acuan Midwifery UpdateTitle.

Orosz, L., Orosz, G., Veress, L., Dosa, D., Orosz, L., Arany, I., Fabian, A., Medve, L., Pap, K., Karanyi, Z., Toth, Z., Poka, R., Than, N. G., \& Torok, O. (2019). Screening for preeclampsia in the first trimester of pregnancy in routine clinical practice in Hungary. Journal of Biotechnology, 300(April), 11-19. https://doi.org/10.1016/j.jbiotec.2019.04 .017

sugiono. (2012). Metode penelitian kuantitatif kualitatif dan $R \& D$. alfabeta.

Villar L., M. A., \& Sibai, B. M. (1989). Clinical significance of elevated mean arterial blood pressure in second trimester and threshold increase in systolic or diastolic blood pressure during third trimester. American Journal of Obstetrics and Gynecology, 160(2), 419-423. https://doi.org/10.1016/00029378(89)90463-8

Wertaschnigg, D., Reddy, M., Mol, B. W. J., Da Silva Costa, F., \& Rolnik, D. L. (2019). Evidence-Based Prevention of Preeclampsia: Commonly Asked Questions in Clinical Practice. Journal of Pregnancy, 2019. https://doi.org/10.1155/2019/2675101 
Tabel 1. Distribusi frekuensi ibu hamil yang preeklamsia di Puskesmas Bontobangun Kabupaten Bulukumba Periode Tahun 2018 - 2019

\begin{tabular}{lcc}
\hline \multicolumn{1}{c}{ VARIABEL } & f & \% \\
\hline KELOMPOK UMUR & & \\
$\quad$ Tidak Berisiko & 24 & 77.4 \\
Berisiko & 7 & 22.6 \\
PARITAS & & \\
$\quad$ Primipara & 14 & 45.2 \\
$\quad$ Multipara & 17 & 54.8 \\
MAP & & \\
$\quad$ Tidak Berisiko & 24 & 77.4 \\
$\quad$ Berisiko & 7 & 22.6 \\
\hline \multicolumn{1}{c}{ Jumlah (n) } & $\mathbf{3 1}$ & $\mathbf{1 0 0}$ \\
\hline
\end{tabular}

Tabel 2. Distribusi frekuensi ibu hamil yang normal di Puskesmas Bontobangun Kabupaten Bulukumba Periode Tahun 2018 - 2019

\begin{tabular}{lcc}
\hline \multicolumn{1}{c}{ VARIABEL } & f & \% \\
\hline KELOMPOK UMUR & & 77.4 \\
Tidak Berisiko & 24 & 22.6 \\
Berisiko & 7 & \\
PARITAS & & 45.2 \\
$\quad$ Primipara & 14 & 54.8 \\
Multipara & 17 & 93.5 \\
MAP & 29 & 6.5 \\
$\quad$ Tidak Berisiko & 2 & $\mathbf{1 0 0}$ \\
\hline Berisiko & $\mathbf{3 1}$ & \\
\hline \multicolumn{2}{l}{ Jumlah (n) }
\end{tabular}

Tabel 3.Hubungan MAP dengan kejadian preeklamsia di Puskesmas Bontobangun Kabupaten Bulukumba Periode Tahun 2018 s.d 2019

\section{Paired Samples Test}

\begin{tabular}{|c|c|c|c|c|c|c|c|c|c|}
\hline & & \multicolumn{5}{|c|}{ Paired Differences } & \multirow{3}{*}{$\mathrm{t}$} & \multirow{3}{*}{ df } & \multirow{3}{*}{$\begin{array}{l}\text { Sig. (2. } \\
\text { tailed) }\end{array}$} \\
\hline & & \multirow[t]{2}{*}{ Mean } & \multirow{2}{*}{\begin{tabular}{|c|} 
Std. \\
Deviati \\
on
\end{tabular}} & \multirow[t]{2}{*}{$\begin{array}{l}\text { Std. } \\
\text { Error } \\
\text { Mean }\end{array}$} & \multicolumn{2}{|c|}{$\begin{array}{l}95 \% \text { Confidence } \\
\text { Interval of the } \\
\text { Difference }\end{array}$} & & & \\
\hline & & & & & Lower & Upper & & & \\
\hline \multirow[t]{2}{*}{ Pair 1} & MAP - & & & & & & & & \\
\hline & $\begin{array}{l}\text { MAP_pre_ } \\
\text { eklamsia }\end{array}$ & $4.838^{-}$ & 12.335 & 2.215 & -9.363 & -.314 & $2.184^{-}$ & 30 & .037 \\
\hline
\end{tabular}

